\title{
Selective, Activity-Dependent Uptake of Histamine into an Arthropod Photoreceptor
}

\author{
Ann E. Stuart, Jennifer R. Morgan, Harold E. Mekeel, Elizabeth Kempter, and Joseph C. Callaway \\ Department of Physiology, University of North Carolina at Chapel Hill, Chapel Hill, North Carolina 27599-7545
}

The synapses made by many arthropod photoreceptors are disinhibitory and use histamine as their transmitter. Because decreases and not increases in the cleft concentration of transmitter constitute the important event at these synapses, a transporter to clear the cleft of histamine would seem particularly crucial to signal transfer. We report here that ${ }^{3} \mathrm{H}$-histamine is taken up selectively into barnacle photoreceptors by a $\mathrm{Na}^{+}$dependent mechanism, presumably a transporter. Using light microscopic autoradiography, we observe heavy label over axons and presynaptic terminals of these neurons when they are stimulated during uptake. The radioactivity taken up was identified as ${ }^{3} \mathrm{H}$-histamine by thin layer chromatography; no metabolites were detected, even after $5 \mathrm{hr}$. Radiolabeled 5-hydroxytryptamine and GABA are not taken up by the photoreceptor. ${ }^{3} \mathrm{H}$-histamine uptake into photoreceptors is de- creased markedly by an excess of unlabeled histamine and by chlorpromazine and phenoxybenzamine. Unexpectedly for uptake dependent on the $\mathrm{Na}^{+}$gradient, photoreceptor terminals label more intensely in the light (when depolarized) than in the dark (when hyperpolarized). Glia label more strongly than photoreceptors in dark-incubated preparations. The presence of presynaptic uptake strengthens the evidence that histamine is the neurotransmitter of arthropod photoreceptors and provides a mechanism by which this synapse could recycle transmitter, control its steady-state cleft concentration, and clear it from the cleft in response to decreases in its release from the photoreceptors.

Key words: histamine; photoreceptor; arthropod; transporter; bamacle; autoradiography; neurotransmitter; synapse; disinhibition
Disinhibition is a common synaptic mechanism in retinas of both vertebrates and invertebrates. In arthropod simple and compound eyes, disinhibition of postsynaptic cells at the photoreceptor synapses converts presynaptic hyperpolarizations to postsynaptic depolarizing synaptic potentials. In steady light, the photoreceptors are depolarized and continuously release inhibitory transmitter, holding the postsynaptic cell silent. Dimming of the light hyperpolarizes the photoreceptor but excites the postsynaptic cell through disinhibition. At such synapses where decreases in concentration of transmitter in the cleft constitute the meaningful signal, the mechanisms of transmitter removal from the cleft might be expected to assume pivotal importance in the generation of the postsynaptic response.

Here we present autoradiographic and biochemical evidence for selective uptake into an arthropod photoreceptor of histamine, the probable neurotransmitter of many, perhaps all, arthropod photoreceptors (Hardie, 1987, 1988, 1989; Simmons and Hardie, 1988; Battelle et al., 1991; Stuart and Callaway, 1991; Burg et al., 1993; Schmid and Duncker, 1993). Uptake is $\mathrm{Na}^{+}-$ dependent, suggesting that this putative histamine transporter belongs to one of the families of $\mathrm{Na}^{+}$-dependent transporters. All domains of the cell took up ${ }^{3} \mathrm{H}$-histamine, although when the cells were stimulated, uptake was markedly greater in the presynaptic

Received Oct. 19, 1995; revised Feb. 7, 1996; accepted Feb. 19, 1996.

This research was supported by United States Public Health Service Grant EY03347 to A.E.S. We thank Dawn Merrick for technical assistance with thin layer chromatography, and Robert T. Fremeau and Kevin E. Martin for reading and criticism of this manuscript. Kevin E. Martin participated in some of the experiments.

Correspondence should be addressed to Dr. Ann E. Stuart, Department of Physiology, University of North Carolina, Chapel Hill, NC 27599-7545.

Dr. Callaway's present address: Department of Anatomy and Neurobiology, University of Tennessee, Memphis, TN 38163.

Copyright $(\mathcal{C} 1996$ Society for Neuroscience $0270-6474 / 96 / 163178-11 \$ 05.00 / 0$ terminals and axons than in the somata and dendrites. Unexpectedly, the terminals of photoreceptors incubated in the light labeled more heavily than those of photoreceptors incubated in the dark, where label was found over glia instead.

Some of these results have been published previously in abstract (Stuart and Mekeel, 1990; Stuart et al., 1993; Morgan and Stuart, 1995).

\section{MATERIALS AND METHODS}

Animals and preparations. Giant barnacles (Balanus nubilus) were obtained from Bio-Marine Enterprises (Seattle, WA) and maintained at $11^{\circ} \mathrm{C}$ in aerated, circulating artificial seawater. Preparations were dissected as described in Hudspeth and Stuart (1977) in barnacle saline containing (in mM): $461.5 \mathrm{NaCl}, 8 \mathrm{KCl}, 20 \mathrm{CaCl}_{2}, 12 \mathrm{MgCl}_{2}$, and 10 Tris(hydroxymethyl) aminomethane $\mathrm{HCl}$ buffer, $\mathrm{pH} 7.6-7.8$.

Preparations consisted of the median eye (ocellus), comprising four photoreceptor somata, the median ocellar nerve containing their axons, and the small supraesophageal ganglion, or "brain," where these photoreceptors terminate (see Fig. $2 A$ ). Two other simple eyes positioned laterally in the animal each contain three photoreceptors that normally project through the antennular nerves to terminate in the ganglion; these nerves (and thus the lateral photoreceptor axons) were severed.

Incubations. ${ }^{3} \mathrm{H}$-histamine dihydrochloride $(36-57 \mathrm{Ci} / \mathrm{mmol}$; Amersham) was divided into $20 \mu \mathrm{l}$ aliquots, and for each experiment an aliquot was dried down to remove ethanol and redissolved in barnacle saline to a concentration of $20 \mu \mathrm{M}, \mathrm{pH}$ 7.3. Preparations were pinned on Sylgard (Dow-Corning), in either small petri dishes or a three-compartment Plexiglas chamber. For preparations in the petri dish, a Vaseline well was constructed around the ocellus (containing the somata and dendrites of the photoreceptors), around the midportion of the ocellar nerve (containing their axons), or around the ganglion (containing their presynaptic terminals); when the Plexiglas chamber was used, the preparation was arranged so that ocellus, nerve, and ganglion were in the separate compartments isolated by Vaseline walls. The saline within the well or one of the compartments was replaced with saline $(20 \mu \mathrm{l})$ containing the $20 \mu \mathrm{M}{ }^{3} \mathrm{H}$-histamine, leaving the rest of the preparation in normal saline outside the well. The fluid level within the well or compartment was 
watched carefully to ensure that it did not decrease during the incubation, which would have indicated a leak in the Vaseline wall, in some cases aliquots were taken of the fluid outside the well to check for leaking radioactivity Incubations in the ${ }^{3} \mathrm{H}$-histamine were for $15 \mathrm{~min}$ at $15^{\circ} \mathrm{C}$ in constant light of moderate intensity $\left(013 \mathrm{~mW} / \mathrm{cm}^{2}\right)$, flashing light of the same intensity ( $2 \mathrm{sec}$ on $/ 6 \mathrm{sec}$ off), or dark When the incubation saline was to contain a drug or altered ionic composition, the saline within the well was exchanged for experımental salıne for 15-30 mun before the ${ }^{3} \mathrm{H}$-histamine was introduced

For $\mathrm{Na}^{+}$-free incubdtions, it was important to superfuse the axons or termınals contınuously for a period of $30 \mathrm{~min}$ to wash completely the $\mathrm{Na}^{+}$ from the extracellular space, exchange for a shorter tıme gave varıble results $\mathrm{Na}^{+}$was replaced with cholıne, tetramethylammonium $\left(\mathrm{TMA}^{+}\right)$, $N$-methyl-D-glucamine $\left(\mathrm{NMG}^{+}\right)$, or $\mathrm{Li}^{+}$For experiments in which physiological activity was monitored during the exposure of axons to $\mathrm{Na}^{+}$-free saline, a preparation in a three-chambered bath was placed on a physology setup Each chamber was superfused continuously with salıne at a high rate $(2-5 \mathrm{ml} / \mathrm{min})$, and visual signals (a burst of activity in third-order ganglion cells at the offset of a light pulse delivered every $20 \mathrm{sec}$ ) were monitored throughout the experiment from one of the circumesophageal connective nerves of the supraesophageal ganglion in which the photoreceptors terminate When ${ }^{3} \mathrm{H}$-histamine was added to the axonal chamber, the perfusion of only that compartment was stopped for the duration of the incubation After incubations, the ${ }^{3} \mathrm{H}$-histamine was washed out for $30 \mathrm{~min}$ in $\mathrm{Na}^{+}$-free saline

Reagents were purchased from Sigma (St Lous, MO) except where noted ${ }^{3}$ H-5-hydroxytryptaminc (Amersham or New England Nuclear) was applied at $40 \mu \mathrm{M}(182$ or $247 \mathrm{Cl} / \mathrm{mmol})$ for experiments on the ganglion and $20 \mu \mathrm{M}$ for experiments on the axons and ocellus, ${ }^{3} \mathrm{H}-\mathrm{GABA}$ (Amersham) was applied at $20 \mu \mathrm{M}(516$ or $86 \mathrm{Cl} / \mathrm{mmol})$ Drugs included phenoxybenzamine and cocaine (generous gifts of Dr Richard Mailman), chlorpromazine, and desipramine

After the incubation, the solution in the Vaseline well (capacity, 20 $\mu$ ) was exchanged quickly with several volumes of either normal saline or, especially when the presynaptıc terminals were incubated, a salıne containing $\mathrm{Co}^{2+}(125 \mathrm{~mm})$ and low $\mathrm{Ca}^{2+}(25 \mathrm{mM})$ to minimize release of the ${ }^{3} \mathrm{H}$-histamine taken up This concentration of $\mathrm{Co}^{2+}$ and $\mathrm{Ca}^{2+}$ has been shown to reduce the postsynaptic response to near zero ( $\mathrm{C}$ Calldwdy and $A$ E Stuart, unpublished observations) The preparation was then immersed in the $\mathrm{C}^{2+} / \mathrm{lnw} \mathrm{Ca}^{2+}$ salıne and transferred on its Sylgard platform to a chamber made from a $5 \mathrm{ml}$ syringe in which it was washed with chilled $\mathrm{Co}^{2+} /$ low $\mathrm{Ca}^{2+}$ salıne for $15-20 \mathrm{~min}(2-3 \mathrm{ml} / \mathrm{min})$ Fifteen minutes after the beginning of the wash, $<1 \%$ of the radioactivity collected during the first minute remaned in the ganglion Axons incubated in ${ }^{3} \mathrm{H}$-histamine in $\mathrm{Na}^{+}$-free saline were washed after incubation with a $\mathrm{Na}^{+}$-free salıne for $30 \mathrm{~mm}$ at $5 \mathrm{ml} / \mathrm{min}$

For preparations incubated in the dark, all manıpulatıons were carried out in total darkness unttl the incubation was terminated and the preparation had been washed for at least $5 \mathrm{~min}$ in $\mathrm{Co}^{2+}$-containıng salıne

Autoradıography Glutaraldehyde (E M Sciences) fixatıve was mod1fied from Hudspeth and Stuart (1977) to contain $02 \mathrm{M} \mathrm{Na}^{+}$cacodylate, $\mathrm{pH} 77$, instead of phosphate buffer Preparations were fixed for times ranging from $1 \mathrm{hr}$ to overnight, washed several times with cacodylate buffer on a tissue rotator, postfixed in osmium tetroxide (1\%) in cacody late buffer ( $1 \mathrm{hr}$, room temperature), washed several times in distilled water, and dehydrated Preparations were cut into pieces at this point so that the ocellus, median portion of the ocellar nerve, and ganglion could be embedded separately in Epon

Blocks were sectioned serially at $2 \mu \mathrm{m}$ Sections were dried on gelatıncoated slides, dipped in Kodak NTB-2 autoradiographic emulsion, exposed at $4^{\circ} \mathrm{C}$ for $5 \mathrm{~d}$ to 2 weeks, and developed in D-19 (Kodak)

Assay of ${ }^{3} H$-histamine uptake by scintillation counting Preparations were incubated in $100 \mu \mathrm{l}$ of $20 \mu \mathrm{M}{ }^{3} \mathrm{H}$-histamine for $15 \mathrm{~min}$ at $15^{\circ} \mathrm{C}$ in Eppendorf tubes in flashing light When appropriate, preparations were preincubated with drug for $15 \mathrm{~min}$ in the dark at $15^{\circ} \mathrm{C}$ After incubation, preparations were washed with 5 vol of a $125 \mathrm{mM} \mathrm{Co}^{2+} / 25 \mathrm{mM} \mathrm{Ca}^{2+}$ salıne One hundred microliters of $6 \%$ trichloroacetic acid were added to each preparation, which then sat overnight at $4^{\circ} \mathrm{C}$ Each preparation was then ground in a glass/glass homogenizer in a final volume of $120 \mu \mathrm{l}$ Aliquots of the homogenate were counted in Biofluor scintillate Protein was determined from the remainder of each sample usıng a Micro BCA protein assay (Pierce, Rockford, IL)

Thin layer chromatography Preparations were incubated in ${ }^{3} \mathrm{H}$ histamine for 2-5 hr in flashing light at $15^{\circ} \mathrm{C}$ After incubation, the preparations were washed for $20 \mathrm{~min}$ in room light with saline solution contaınıng $\mathrm{Co}^{2+}(125 \mathrm{~mm})$ and low $\mathrm{Ca}^{2+}(25 \mathrm{mM})$ The nerves were severed, the ocellus was discarded, and the washed ganglia were homogenized in $50 \mu \mathrm{l}$ of a mixture of $1 \mathrm{M}$ formic acid and acetone (15 85) The extract was chromatographed on Polygram SII. G sheets (MachereyNagel, Duren, Germany) in solvent systems of chloroform/methanol/ ammonium in proportions of 1271 or 221 (Weinreich et al, 1979, Elias and Evans, 1983) The unlabeled metabolites, imidazole acetic acid (Sigma), $N$-acetyl histamine (Sıgma), $N$-telemethylhistamine (gift of Merck, Sharpe and Dohme) and $\gamma$-glutamylhıstamıne (kındly provided by Dr D Wemreicli), were added al a concentration of $1-2 \mathrm{mg} / \mathrm{ml}$ to samples before chromatography and were visualized using a sulfanilic acid stain (Elias and Evans, 1983) or $02 \%$ ninhydrin in acetone After chromatography, each lane was cut into $05 \mathrm{~cm}$ sections, eluted in $100 \mu \mathrm{l}$ $01 \mathrm{M} \mathrm{HCl}$, and counted in Scintiverse BD (Fisher) All solvents were HPLC grade from Fisher

\section{RESULTS}

\section{Photoreceptor terminals take up ${ }^{3} \mathrm{H}$-histamine}

The ganglia of 19 preparations containing the presynaptıc termınals of the photoreceptors were incubated in ${ }^{3} \mathrm{H}$-histamine $(20$ $\mu \mathrm{M})$ Ganglia were ringed with Vaselıne and incubated for $15 \mathrm{~mm}$ at $15^{\circ} \mathrm{C}$, during which time the preparations were stımulated etther with flashing light (standard conditions) or, for several preparations, with steady light Subsequent autoradiography showed that in all of these preparations, label was highly localized within the ganglion to the terminal regions of the photoreceptors, including their axons and their entıre presynaptic arbors (Fig $1 A-C$ )

Figure $1 A, B$ shows phase-contrast and dark-field views, respectively, of a horizontal section taken at the level of the photoreceptor terminals through the ganglion of a preparation that had been incubated in ${ }^{3} \mathrm{H}$-histamine and steady light The section has the location and approximate dimensions of the rectangle drawn on the ganglion in the diagram of Figure $2 A$ Each photoreceptor axon bifurcates at a variable position in the nerve as it enters the midline of the commissure linkıng the two hemıganglia (Hudspeth and Stuart, 1977, theır Fig 6) and then arborizes bilaterally close to the midline, this section passes through the heart of the arbors of these cells Silver grains distinctly outline the arbors in their entrety, mcluding the axons as they enter the ganglion, their primary branches, and their rather abrupt, bushy terminals (Schnapp and Stuart, 1983, Stockbridge and Ross, 1984, Oland and Stuart, 1986, Callaway et al, 1989, Callaway et al, 1993) The presence of grains over the entering axons (arrows in Fig 1A) was unexpected but repeatable, longer portions of the axons of the entering photoreceptors in a section from another preparation show clearly their marked labeling (arrows in Fig $1 C$ )

The section shown in Figure $1 A, B$ is from a serial set of 126 sections through the ganglion, in which 25 sections near the center of the set (sections 29 through 53) showed silver grains in the expected position of the photoreceptor terminals The primary processes and final arbors extend in this preparation $\sim 100-150$ $\mu \mathrm{m}$ into each hemiganglion, in agreement with previous measurements from horseradısh peroxıdase-filled cells (Schnapp and Stuart, 1983) In a second preparation (Fig $1 C$ ), terminals appeared in 23 of 71 serral sections that were cut Thus, the termmal arbors occupied about the same vertical dimension in the two ganglia $(46-50 \mu \mathrm{m})$ and were present in a substantial fraction of the serial sections

At lower magnification, it was possible to see that grains were distributed evenly within the main body of the ganglion (not shown), suggestıng no substantial accumulation of the ${ }^{3} \mathrm{H}-$ histamine either in ganglion cells or in the glia surrounding them This finding contrasts markedly with the dense pattern of label, 

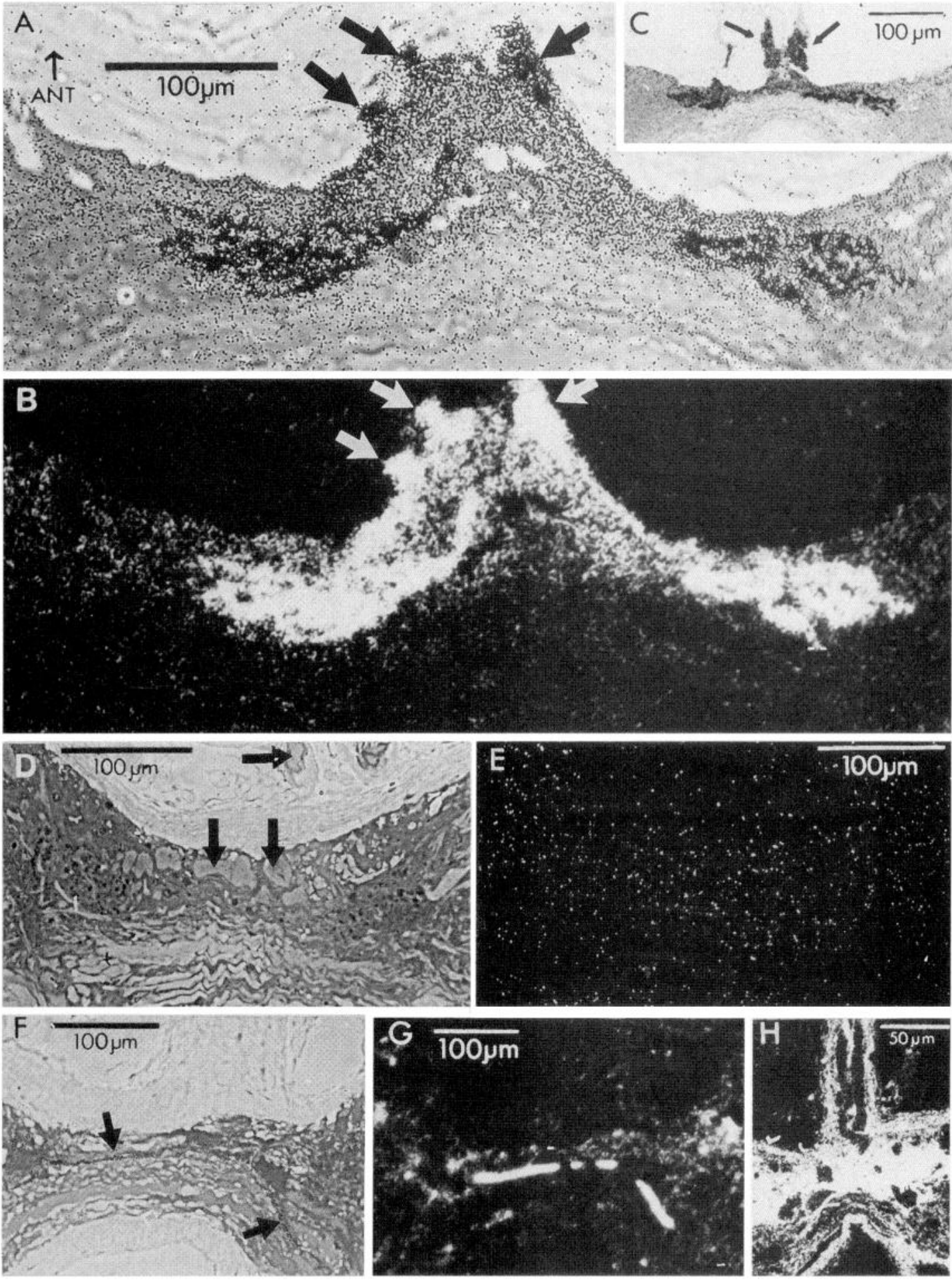

Figure 1. Labeling of photoreceptor terminal arbors after incubation in ${ }^{3} \mathrm{H}$-histamine $(A-E),{ }^{3} \mathrm{H}-5 \mathrm{HT}(F, G)$, or ${ }^{3} \mathrm{H}-\mathrm{GABA}(H)$ in the light. $A$, Horizontal section of the ganglion as seen with phase-contrast illumination. Silver grains crisply delineate photoreceptor axons (fat arrows), primary processes, and bilaterally symmetrical terminal arborizations in the anterior portion of the commissure linking the two hemiganglia. The concentration of ${ }^{3} \mathrm{H}$-histamine was $20 \mu \mathrm{M}$ in this and all other incubations involving ${ }^{3} \mathrm{H}$-histamine. $B$, Dark-field illumination of the same section. Scale bar in $A$ applies also to $B$. $C$, A section from another preparation photographed with phase-contrast illumination. The axons in the median ocellar nerve (arrows) are particularly prominent in this preparation. Both preparations were incubated in the constant light. Sections were $2 \mu \mathrm{m}$ and were exposed to emulsion for 2 weeks. $D$, Bright-field view of section through a preparation incubated in $2 \mathrm{mM}$ unlabeled histamine and $20 \mu \mathrm{M}{ }^{3} \mathrm{H}$-histamine. No accumulation of silver grains is apparent over the photoreceptor axons or primary processes (arrows) or photoreceptor terminals in the ganglion. The lack of silver grains over this and all the other serial sections of this preparation is consistent with the unlabeled histamine outcompeting ${ }^{3} \mathrm{H}$-histamine for uptake. $E$, Dark-field view of the section in $D . F$, Bright-field view of a preparation incubated in ${ }^{3} \mathrm{H}-5 \mathrm{HT}$. The label is absent from photoreceptors and glia but is associated with a fragment of axon (arrows) and varicosities in the neuropil. $G$, Dark-field view of the section in $F$. $H$, Section through the nerve as it enters the ganglion from a preparation incubated in ${ }^{3} \mathrm{H}-\mathrm{GABA}$ viewed in dark-field illumination. Silver grains are found over glia but are conspicuously lacking over the bifurcating photoreceptor axons. Anterior is up in all panels. 

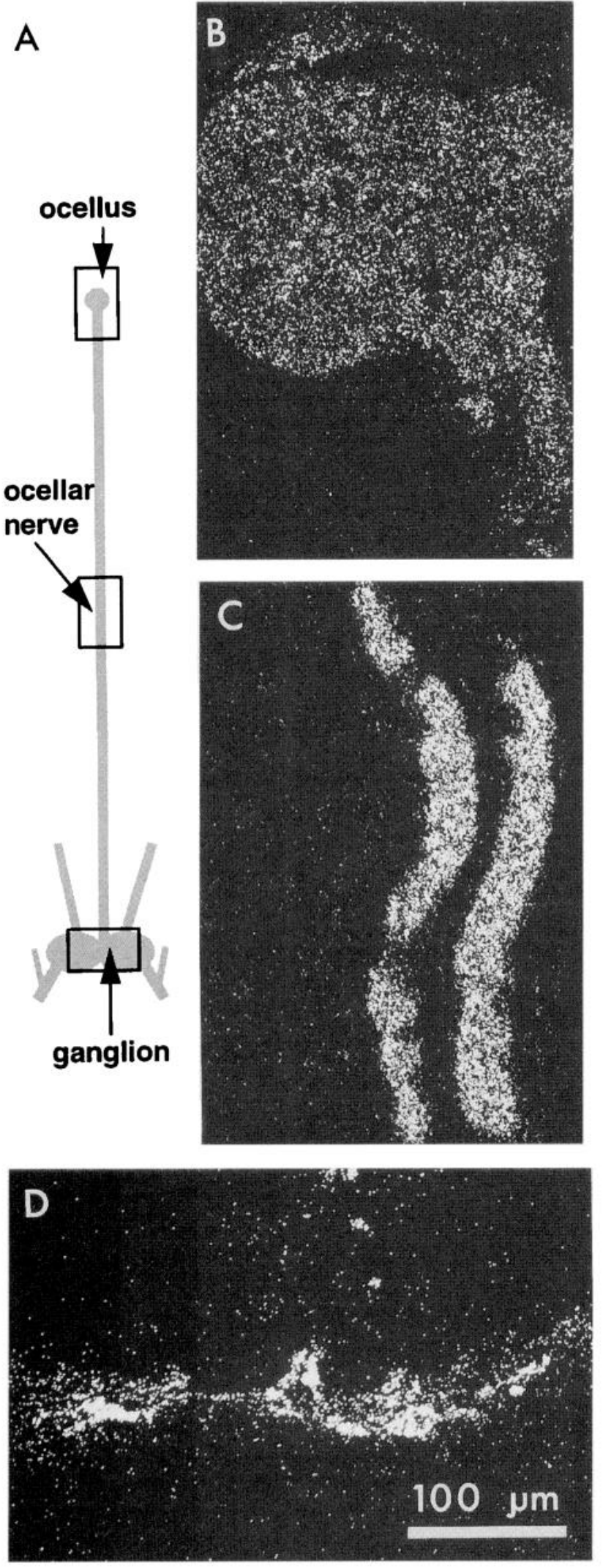

Figure 2. Distribution of uptake in intact photoreceptors when the whole preparation was incubated in ${ }^{3} \mathrm{H}$-histamine. $A$, Diagram of the preparation (not drawn to scale) showing the median ocellus, ocellar nerve, and ganglion to which it projects. Sections through the regions indicated by the rectangles are shown in dark-field illumination on the right. $B$, The ocellus, which shows a uniform and light accumulation of silver grains. $C$, presumably glial, seen after incubation in ${ }^{3} \mathrm{H}-\mathrm{GABA}$, where the grains spare the ganglion cells and photoreceptors but blacken the areas between them (Fig. $1 H$ ).

It was a consistent observation that the "background" label over the anterior half of the commissure in which the photoreceptor terminals arborize was greater than that in the posterior half (Fig. $1 A$ ) or, indeed, than over the rest of the ganglion. This label over the anterior commissure seems to be over the distinctive glial cells that envelope the photoreceptor arbors in this region (Schnapp and Stuart, 1983). Packed, unlabeled axons form the posterior half of the commissure, which is clearly distinct from the anterior half in this phase-contrast view.

The accumulation of ${ }^{3} \mathrm{H}$-histamine in the axons and terminals of the median photoreceptors was diminished markedly in each of two preparations by $2 \mathrm{~mm}$ unlabeled histamine added to the incubation medium (Fig. $1 D, E$ ), an observation consistent with uptake being a competitive process, presumably mediated by a transporter protein.

\section{${ }^{3} \mathrm{H}-5$-hydroxytryptamine $(5 \mathrm{HT})$ and ${ }^{3} \mathrm{H}-\mathrm{GABA}$ are not taken up by photoreceptor terminals}

Two ganglia incubated in ${ }^{3} \mathrm{H}-5 \mathrm{HT}(40 \mu \mathrm{M})$ and flashing light did not show an accumulation of grains over photoreceptor terminal arbors. Rather, these preparations accumulated silver grains over a decussating ganglion cell axon (Fig. $1 F, G$, fat arrows) in the same region as the unlabeled photoreceptor terminals, over varicosities in the neuropil, and over several small cell bodies (not in the section of Fig. $1 F, G$ ) in the pattern observed by Callaway et al. (1985) using immunolabeling. Thus, the uptake of ${ }^{3} \mathrm{H}$-histamine into the photoreceptors is highly selective for histamine over 5HT.

Two ganglia incubated in ${ }^{3} \mathrm{H}$-GABA $(20 \mu \mathrm{M})$ labeled widely and diffusely, presumably attributable to uptake of this compound into glial cells. There was no label over photoreceptor terminal arbors, axons (Fig. $1 H$, dark, unlabeled, elongated profiles in the nerve), or other neurons. Curiously, GABA antiserum labels barnacle photoreceptor somata and axons and (less intensely) their presynaptic arbors (Callaway et al., 1989). Strong arguments, however, previously have disqualified GABA as the transmitter causing the postsynaptic response (Callaway and Stuart, 1989a) and now include the absence of ${ }^{3} \mathrm{H}-\mathrm{GABA}$ uptake into the terminals.

\section{Distribution of ${ }^{3} \mathrm{H}$-histamine along the photoreceptor neuron}

Incubation of whole preparations $(n=3)$ in ${ }^{3} \mathrm{H}$-histamine in flashing light, and subsequent autoradiography of their ocelli, axons, and terminals (Fig. 2) confirmed that label appeared not only over the terminals of the photoreceptors (Fig. $2 D$ ) but also over their axons in the nerve (two axons captured in Fig. 2C). Other, smaller axons in the nerve, not belonging to photoreceptor neurons, did not label. Ocellar structures (Fig. $2 B$ ) labeled at a density above that in the surrounding capsule, but the label was apparently uniform and far less dense than in the axons. In fact, a gradient of label seems to exist in the preparation of Figure 2, with the terminals most intensely labeled, but because the axons were

\footnotetext{
The nerve. This section cuts through two photoreceptor axons that are labeled more heavily than ocellar structures. Other axons in the nerve are not labeled. $D$, The portion of the ganglion containing the photoreceptor synaptic terminals, which are also heavily labeled. Scale bar applies to $B, C, D$.
} 

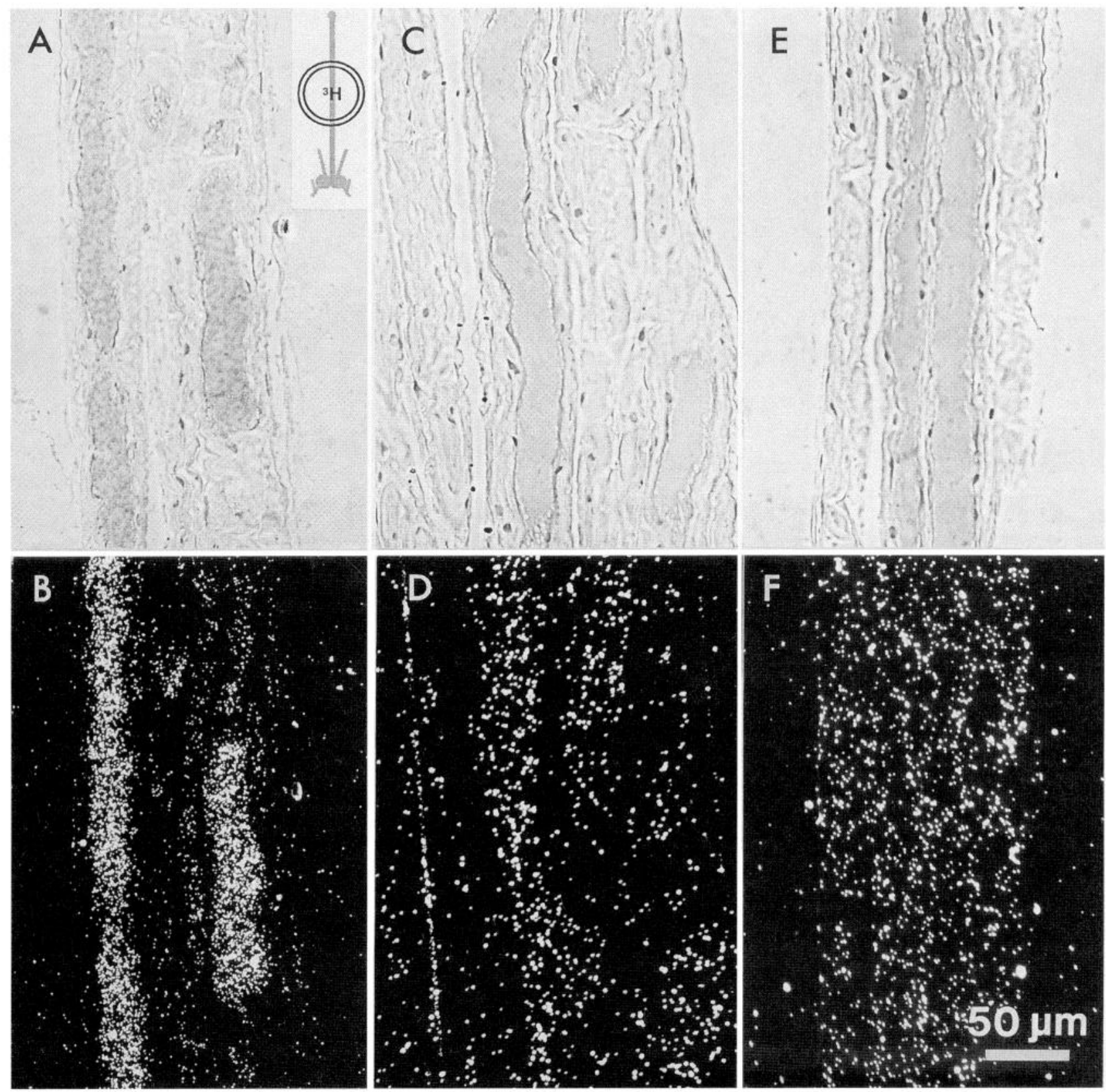

Figure 3. Labeling of photoreceptor axons when only the median ocellar nerve was incubated in ${ }^{3} \mathrm{H}$-histamine (inset diagram). A, B, Phase-contrast and dark-field micrographs, respectively, of a section through the median ocellar nerve in which portions of two photoreceptor axons are seen. Only the photoreceptor axons labeled when incubated in ${ }^{3} \mathrm{H}$-histamine; other structures within the nerve did not accumulate grains above background seen in the surrounding capsule. $C, D$, Label in the photoreceptor axons is reduced to background level when $1 \mathrm{~mm}$ unlabeled histamine is added to the $20 \mu \mathrm{M}$ ${ }^{3} \mathrm{H}$-histamine. $E, F$, The photoreceptor axons do not take up ${ }^{3} \mathrm{H}-5 \mathrm{HT}$. Scale bar shown in $F$ applies to all panels.

sampled only at their midpoint and not at other positions along their length, it was not possible to know from these experiments whether the entire cell labeled as a gradient or as three discrete domains of intensity.

\section{Photoreceptor axons take up ${ }^{3} \mathbf{H}$-histamine}

From the experiments illustrated in Figures 1 and 2, we did not know whether the ${ }^{3} \mathrm{H}$-histamine was being accumulated actively by the axons of the photoreceptors or whether it was diffusing or being retrogradely transported into the axons from the terminals. To determine whether the axons of the photoreceptors themselves could take up ${ }^{3} \mathrm{H}$-histamine, only the middle portion of the nerve was incubated in the labeled compound (Fig. 3 , inset diagram; $n=$ 5). The ganglion and ocellus were bathed in unlabeled histamine (1 mM) to prevent uptake at these sites of ${ }^{3} \mathrm{H}$-histamine that might have leaked out of the axonal compartment or diffused along extracellular pathways. Subsequent autoradiography and examination with phase-contrast and dark-field optics (Fig. 3A,B) showed heavy label over the photoreceptor axons in the nerve. Figure $3 A$, focused on the tissue, shows the large size of the photoreceptor axons in relation to the diameter of the nerve. Other smaller axons and structures within the nerve do not 


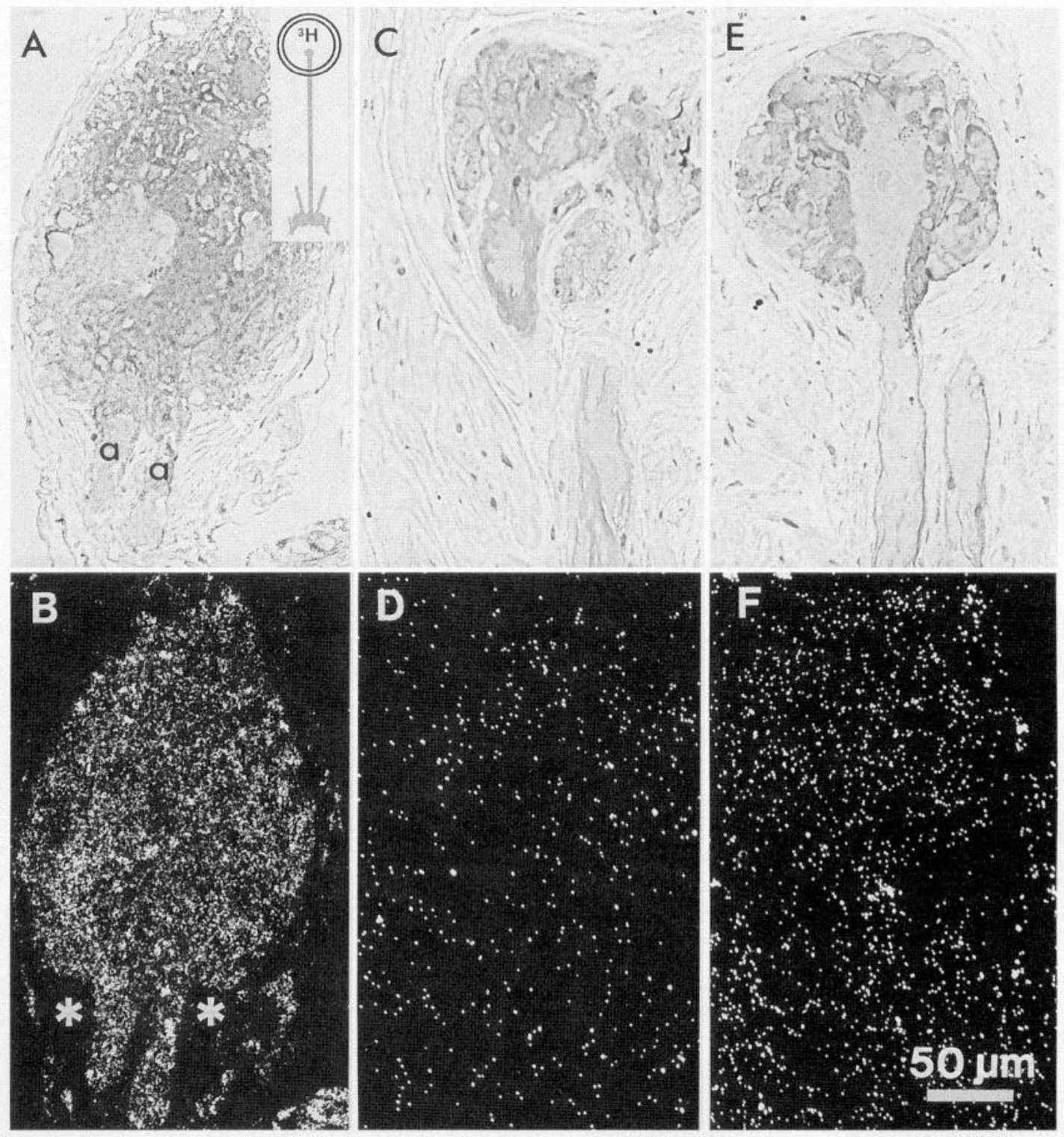

Figure 4. Labeling of the median ocellus after incubation in ${ }^{3} \mathrm{H}$-histamine (inset diagram). $A, B$, Horizontal section through the median ocellus, showing the axon hillocks $(a)$ of two photoreceptors exiting it. A uniform accumulation of silver grains is seen over ocellar structures at higher density than over surrounding capsule (asterisks in $B$ ). C, D, $1 \mathrm{mM}$ unlabeled histamine added to the $20 \mu \mathrm{M}{ }^{3} \mathrm{H}$-histamine. The uptake of ${ }^{3} \mathrm{H}$-histamine is reduced to the background level seen over the capsule. $E, F$, A section through an ocellus incubated in ${ }^{3} \mathrm{H}-5 \mathrm{HT}$. The sectioned photoreceptor soma, its dendrites, its axon, and a portion of an axon from a neighboring photoreceptor (soma in another section) clearly do not accumulate grains above the background level. Scale bar in $F$ applies to all panels.

accumulate grains above the background density seen over the connective tissue capsule that surrounds the nerve and ganglion.

Excess $(1 \mathrm{~mm})$ unlabeled histamine added to the ${ }^{3} \mathrm{H}$-histamine in the incubation saline blocked the accumulation of grains over the axons (Figs. $3 C, D ; n=2$ ). Incubation of the nerve in ${ }^{3} \mathrm{H}-5 \mathrm{HT}$ $(20 \mu \mathrm{M})$ also resulted in no significant accumulation of silver grains over the photoreceptor axons, or, indeed, over any of the axons in the nerve (Fig. $3 E, F ; n=2$ ). Thus uptake of ${ }^{3} \mathrm{H}$ histamine into the photoreceptor axons has characteristics similar to uptake into the presynaptic terminals.

\section{Pattern of ${ }^{3} \mathbf{H}$-histamine label over ocelli}

In contrast to the clear label of terminals and axons, the label over ocelli incubated in ${ }^{3} \mathrm{H}$-histamine was light and uniform (Fig. $4 A, B$; $n=8$ ). Structures within the barnacle ocellus include the four photoreceptor somata (one seen exceptionally clearly in the section of Fig. $4 C$ ), their dendrites and rhabdomeres, and surrounding glial cells, which are intertwined with the dendrites (Fahrenbach, 1965; Hudspeth and Stuart, 1977). Although the accumulation of grains over ocellar structures was denser than the background level in the capsule (asterisks in Fig. 4A, B), there was no pattern to this label suggestive of selective accumulation into either the neuronal or the glial cells.

When excess (1 $\mathrm{mm})$ unlabeled histamine was added to the incubation solution, the grains were distributed over the ocellus at background level (Fig. 4C,D;n=3), suggesting that the uptake observed in the ocellus, although weak, is a competitive process and not simply entrapment of ${ }^{3} \mathrm{H}$-histamine in the extracellular space.

Ocelli incubated in $20 \mu \mathrm{M}{ }^{3} \mathrm{H}-5 \mathrm{HT}$ (Fig. 4E,F;n=4) did not show accumulation of grains above background over any ocellar 


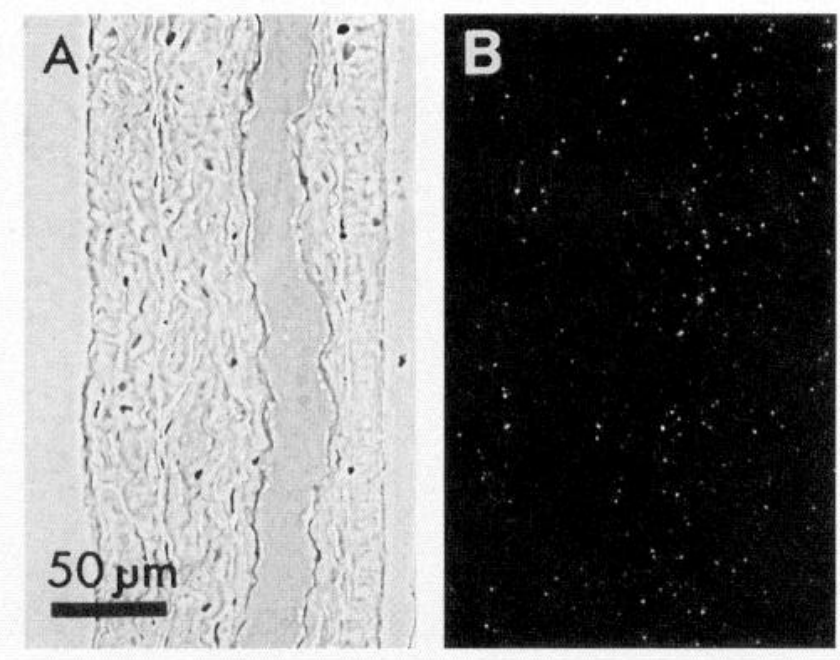

Figure 5. $\mathrm{Na}^{+}$-dependence of the uptake of ${ }^{3} \mathrm{H}$-histamine into axons. $A$, $B$, Phase-contrast and dark-field micrographs, respectively, of a section through a median ocellar nerve that was incubated in $\mathrm{Na}^{+}$-free saline ( $\mathrm{Na}^{+}$replaced by choline), while its ability to signal normally was verified by recording from postsynaptic cells. The absence of label indicates that uptake of ${ }^{3} \mathrm{H}$-histamine is a $\mathrm{Na}^{+}$-dependent process. Scale bar in $A$ also applies to $B$.

structures. In the phase-contrast micrograph of Figure $4 E$, one can see clearly a photoreceptor soma, several of its dendrites, and the axon projecting from it that exits the ocellus. The corresponding dark-field view of this section (Fig. $4 F$ ) reveals no difference in grain density over these structures, the rest of the ocellus, and the capsule. In contrast, the density of silver grains over the ocellus attributable to the uptake of ${ }^{3} \mathrm{H}$-histamine (Fig. $4 A, B$ ) is higher than that over the capsule (asterisks in Fig. 4B).

\section{The uptake of ${ }^{3} \mathrm{H}$-histamine is $\mathrm{Na}^{+}$-dependent}

Using autoradiography, we determined whether ${ }^{3} \mathrm{H}$-histamine could be taken up into photoreceptor axons or terminals in the absence of external $\mathrm{Na}^{+}$. Preparations were placed in a threechamber bath, and the axons were incubated in ${ }^{3} \mathrm{H}$-histamine and saline in which the $\mathrm{Na}^{+}$had been replaced by choline or $\mathrm{TMA}^{+}$ (terminals and ocellus incubated in normal saline). Axons from all six preparations incubated in $\mathrm{Na}^{+}$-free saline showed no accumulation of silver grains (Fig. $5 A, B$ ).

To be certain that the lack of uptake was not attributable to damage to the axons during prolonged exposure to the $\mathrm{Na}^{+}$-free saline, we monitored the function of the photoreceptors in each experiment. Signals are known to spread along the axons of the photoreceptors in a decremental fashion without action potentials, and they do not require extracellular $\mathrm{Na}^{+}$(Hudspeth and Stuart, 1977; Hudspeth et al., 1977). Thus it was possible to monitor the health of the axons during incubations by determining whether visual signals continued to spread from the cell soma to the terminals in the $\mathrm{Na}^{+}$-free saline. Because the ganglion cells and the photoreceptor terminals were bathed in normal saline, synaptic transmission from the photoreceptors and the responses of postsynaptic cells were preserved. Extracellular recordings from a nerve containing the axons of ganglion cells in the visual pathway showed no change in the response of these neurons to changes in light intensity during the entire time of exposure of the photoreceptor axons to $\mathrm{Na}^{+}$-free saline ( $30 \mathrm{~min}$ preincubation, 15 min incubation, $30 \mathrm{~min}$ wash). We conclude that signals spread normally down the photoreceptor axons in the $\mathrm{Na}^{+}$-free saline and that the absence of uptake into the axons in this saline was unlikely to be attributable to axonal damage. Fourteen ganglia were incubated in salines in which $\mathrm{Na}^{+}$had been replaced with choline, $\mathrm{TMA}^{+}, \mathrm{Li}^{+}$, or $\mathrm{NMG}^{+}$. Labeling was either absent or very weak in all of these ganglia, even after 2 weeks of exposure to emulsion. Control ganglia incubated in $\mathrm{Na}^{+}$-containing saline in these experiments labeled normally. On the basis of the markedly diminished labeling and the absence of label from axons in $\mathrm{Na}^{+}$-free salines, we conclude that uptake in the terminals is $\mathrm{Na}^{+}$-dependent. A low concentration of $\mathrm{Na}^{+}$remaining in the extracellular space around the ganglion might be expected to drive uptake to some extent, as is the case for the glutamate transporter (Schwartz and Tachibana, 1990).

\section{Assaying uptake of ${ }^{3} \mathrm{H}$-histamine by scintillation counting}

Preparations were incubated in ${ }^{3} \mathrm{H}$-histamine under standard conditions and assayed separately for uptake using scintillation counting. In 24 preparations (ocellus, median ocellar nerve, and ganglion), the mean accumulation of ${ }^{3} \mathrm{H}$-histamine was $73 \pm 43$ $\mathrm{pmol} / \mathrm{mg}$ protein for a $15 \mathrm{~min}$ incubation. Including $2 \mathrm{~mm}$ unlabeled histamine in the incubation medium reduced uptake by $90 \%$. The time course of the accumulation of the ${ }^{3} \mathrm{H}$-histamine is shown in Figure $6 A$. Uptake is roughly linear for the first $15 \mathrm{~min}$ and approaches saturation by $30 \mathrm{~min}$.

We determined whether the radioactivity was associated primarily with histamine or with a histamine metabolite. Preparations were incubated in ${ }^{3} \mathrm{H}$-histamine $(20 \mu \mathrm{M})$ at $15^{\circ} \mathrm{C}$ and either flashing light for $2 \mathrm{hr}$ (Fig. $6 B$ ) or in the dark for $5 \mathrm{hr}$. Radioactive compounds in these preparations were then separated by thin layer chromatography.

The dominant compound after either of these periods of incubation was ${ }^{3} \mathrm{H}$-histamine (Fig. $6 B$ ). No substantial peaks were seen at the positions of imidazolacetic acid, $N$-acetyl histamine, or $N$-telemethylhistamine, the major metabolites. No peak was seen at the position of $\gamma$-glutamyl histamine, a major metabolite in molluscs (Weinreich, 1979), which would have run just to the left of imidazolacetic acid in this solvent system. Thus, the ${ }^{3} \mathrm{H}$ histamine seems not to be metabolized to any great extent. ${ }^{3} \mathrm{H}$ histamine taken up into Drosophila heads (Sarthy, 1991) or synthesized from ${ }^{3} \mathrm{H}$-histidine (Battelle et al., 1991; Sarthy, 1991) is also not metabolized significantly.

\section{Blocking uptake of ${ }^{3} \mathrm{H}$-histamine into photoreceptor terminals}

Four drugs known to block aminergic transport in general, or histamine uptake in other preparations, were tested for their ability to interfere with the uptake of ${ }^{3} \mathrm{H}$-histamine, assayed by autoradiography. Uptake was not blocked by cocaine (100 $\mu \mathrm{M}$; Fig. $7 A, B)$ or desipramine $(100 \mu \mathrm{M}$; result not shown), but chlorpromazine $(20 \mu \mathrm{M}, n=5$; Fig. $7 C, D)$ or phenoxybenzamine (20 $\mu \mathrm{M}, n=2$; Fig. $7 E, F)$ antagonized labeling of the photoreceptor axons and terminals. Phenoxybenzamine at $7 \mu \mathrm{M}$ blocked uptake in five of eight preparations. Pyrilamine, a histamine $\mathrm{H} 1$ antagonist reported previously to block labeling in autoradiography (Stuart and Mekeel, 1990), also blocked uptake at $100 \mu \mathrm{M}$ as assayed by scintillation counting, but was not pursued further because of the high concentration needed for block.

Chlorpromazine and phenoxybenzamine each exert a dosedependent block of uptake assayed by scintillation counting (Fig. 8 ), with chlorpromazine being the more effective of the two drugs at lower doses. Neither antagonist is high affinity, however, be- 

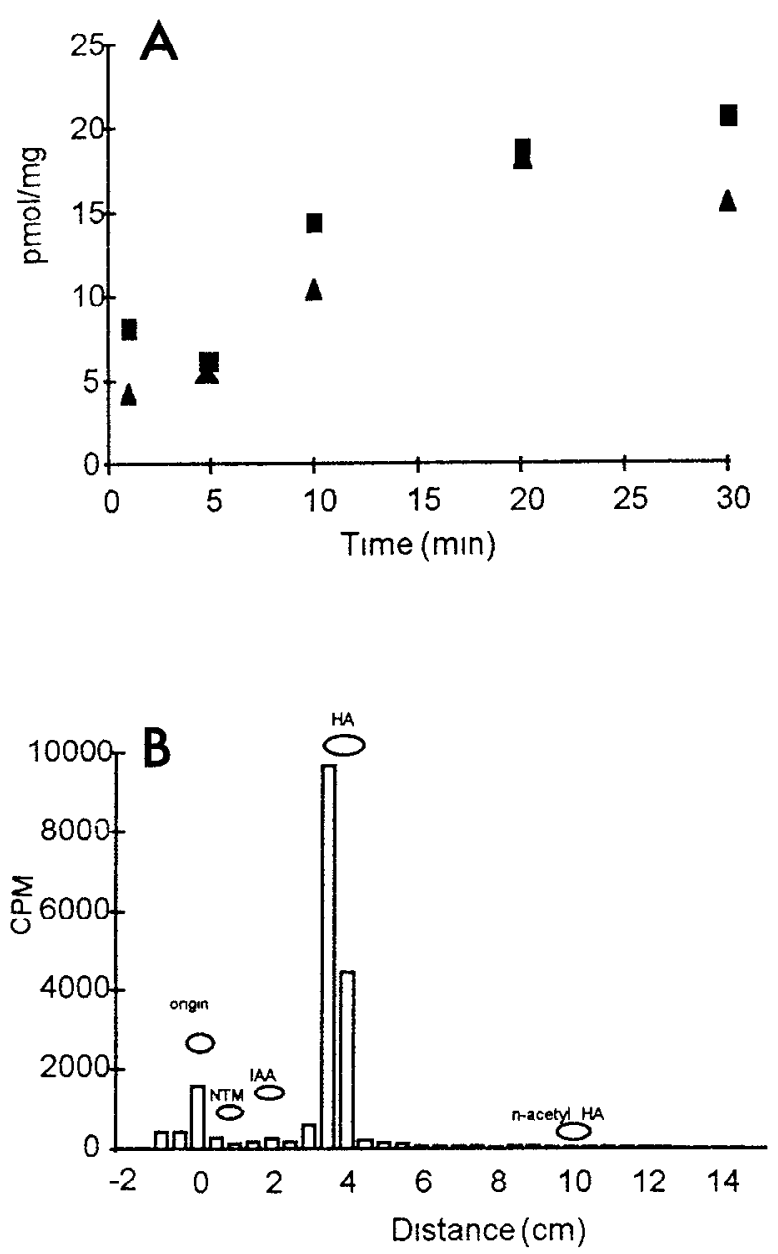

Figure 6 Time course and metabolism of ${ }^{3} \mathrm{H}$-histamine taken up by the preparation $A$, Time course of uptake Whole preparations were incubated in ${ }^{3} \mathrm{H}$-histamine for the time indicated, each point representing a separate preparation Squares and triangles indicate preparations made on 2 different days $B$, Thin layer chromatograph showing radiolabeled compounds present in a preparation after $2 \mathrm{hr}$ of incubation in ${ }^{3} \mathrm{H}$ histamine ( $20 \mu \mathrm{M}$, standard conditions) A large peak of radioactıvity was associated with the histamine standard $(H A)$ No substantial peaks were seen at the positions of major metabolites imidazolacetic acid $(L A A)$, $N$-acetylhistamine ( $n$-acetyl $H A$ ), or $N$-telemethylhıstamıne $(N T M)$ Compounds were extracted from preparations with $1 \mathrm{M}$ formic acid/acetone (15 85), and separated using a $1271 \mathrm{chloroform} / \mathrm{methanol} / \mathrm{ammon}$ ld solvent system

cause their highest concentratıons reduced uptake by only $75 \%$, whereas unlabeled histamine reduced it by $90 \%$ We have reported (Stuart et al , 1993) that chlorpromazine $(20 \mu \mathrm{M})$ prolongs the inhibition of the postsynaptic cell, an effect consistent with blocking transmitter uptake

\section{Photoreceptor terminals incubated in the dark show markedly diminished uptake}

Figure 9 shows sections through photoreceptor axons and regions in which they would be expected to arborize in four preparations incubated in the dark To our surprise, label was found predominantly over glia rather than photoreceptors Axonal profiles in the nerve were outlined by labeled, surrounding glia (Fig 9C), and terminal arbors were labeled weakly or not at all

This result was unexpected because $\mathrm{Na}^{+}$-dependent uptake of transmitters in other preparations increases when cells are relatively hyperpolarized, as would be the case with the dark- incubated photoreceptors, because the $\mathrm{Na}^{+}$gradient is increased (Ayoub and Lam, 1987) These findings suggest that the balance of uptake of ${ }^{3} \mathrm{H}$-histamine into photoreceptor termınals and surrounding glia depends on some process or substance that reflects the state of activity of the photoreceptors

\section{DISCUSSION}

This report that ${ }^{3} \mathrm{H}$-histamine is taken up selectively into barnacle photoreceptors adds a critical piece to the body of evidence that histamine is the transmitter of arthropod photoreceptors Labeling of the terminals was greatest when the photoreceptors were stimulated by light, suggesting that the uptake of histamine is linked to its release at these highly active synapses It is likely that a specific histamine transporter of the superfamily of $\mathrm{Na}^{+}$dependent amınergıc transmitter transporters (Amara and Kuhar, 1993) mediates this uptake This transporter also exists in the glia surrounding the photoreceptors, because there is marked uptake into this compartment when the preparation is incubated in the dark

\section{Selective uptake supports a transmitter role for histamine}

The presence of a removal mechanism is one of the criteria establishing that a given molecule is a transmitter Although the criteria of synthesis, storage, and appropriate postsynaptic action of histamine have been satisfied for varıous arthropod preparations (for review, see Stuart and Callaway, 1991, also see Sarthy, 1991, Burg et al , 1993), uptake into photoreceptors had not been demonstrated clearly before this report ${ }^{3} \mathrm{H}$-histamıne was taken up only into glial cells of locust compound eye (Elias and Evans, 1984) or nonspecifically throughout Drosophila compound eye (Sarthy, 1991) Sarthy (1991) suggests that a permeability barrier interferes with demonstrating uptake into photoreceptors of insect compound eyes There is indirect evidence for uptake into photoreceptors of the compound eye of Limulus (Hart and Battelle, 1991) and locust simple eyes (Schlemermeyer et al, 1989) Furthermore, the compound eyes of barnacle larvae also take up ${ }^{3} \mathrm{H}$-histamine (E Kempter, H E Mekeel, and A E Stuart, unpublished observations) Barnacle photoreceptors take up histamine at a bath concentration of $20 \mu \mathrm{M}$, although we do not know the actual concentration at the terminals, this concentration is within the range effective on postsynaptic cells (Callaway and Stuart, 1989b, Hardie, 1989)

For barnacle photoreceptors, the criteria that have been met to establish histamine as the transmitter (Callaway and Stuart, $1989 b$, Callaway et al, 1989) are that it is stored in the cell, particularly in the presynaptic terminals, that it mimics the effect of transmitter of the photoreceptors on the postsynaptic cell, that Its postsynaptic action is blocked by compounds that block the action of the natural transmitter, and with this report, that it is selectively taken up into the presynaptıc termınals Furthermore, histamine is synthesized by median ocellar nerves and ganglia ${ }^{3} \mathrm{H}$-histamine loaded into the preparation by uptake can be released by externally applıed $100 \mathrm{~mm} \mathrm{~K}^{+}$(Stuart and Callaway, 1991), but release in response to depolarization by light has not been shown for any arthropod photoreceptor

\section{${ }^{3} \mathrm{H}$-histamine uptake into other cell types}

Mast cells, perhaps the best known histaminergic cell type, concentrate histamine in large granules and release it massively in response to a stimulus Although one might expect a specific histamine transporter to be located in the membrane of these cells, this is not the case Instead, histamine is synthesized from 

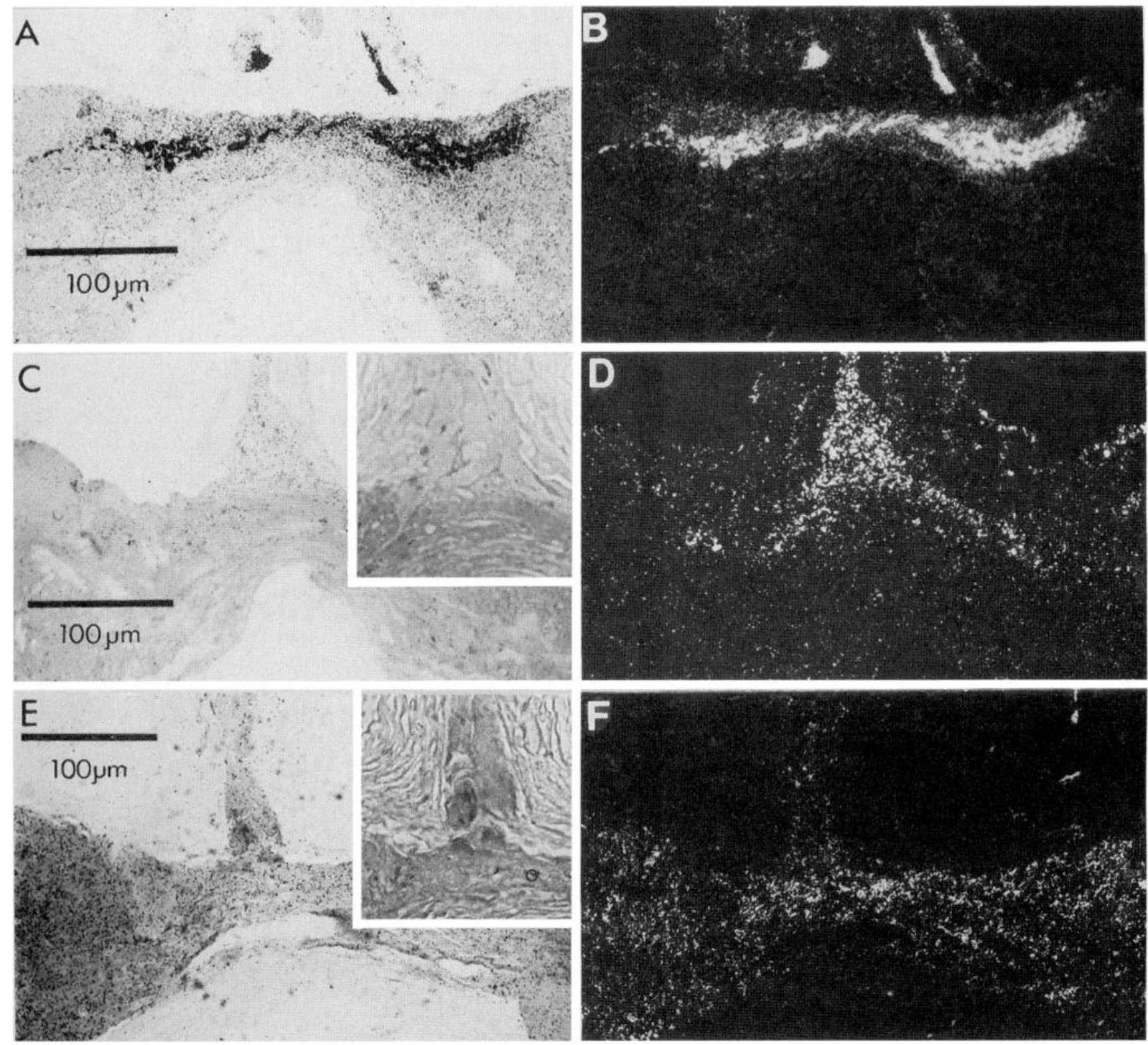

Figure 7. Pharmacological characteristics of ${ }^{3} \mathrm{H}$-histamine uptake. Sections through the photoreceptor axons and expected region of terminals are shown in bright-field illumination (left) with phase-contrast insets to reveal the axon profiles more clearly, and also in dark-field views (right) to make clear the distribution of the grains. $A, B$, Cocaine $(100 \mu \mathrm{M})$ added to the incubation medium did not block labeling of photoreceptor axons and terminals. $C, D$, Chlorpromazine $(20 \mu \mathrm{M})$ added to the incubation medium markedly decreased the labeling of axons, and terminal labeling was not detectable. Insets in this panel and in panel $\mathrm{E}$ show phase-contrast view of photoreceptor axons at the junction of the median ocellar nerve with the commissure. $E$, $F$, Phenoxybenzamine $(20 \mu \mathrm{M})$ also blocked the uptake of ${ }^{3} \mathrm{H}$-histamine into photoreceptor axons and terminals.

histidine and then concentrated in the granules by a protoncoupled general amine carrier that actually prefers $5 \mathrm{HT}$ over histamine (Ludowyke and Lagunoff, 1986). Uptake into barnacle photoreceptors is not by this type of transporter because ${ }^{3} \mathrm{H}-5 \mathrm{HT}$ was not taken up.

Certain neurons located in the hypothalamus of all vertebrate species examined so far (Panula and Airaksinen, 1991) also show high levels of histamine and are likely to use it as a neurotransmitter. There is controversy over whether a transporter exists in these neurons (Schwartz et al., 1991). Vertebrate glial cells, however, seem to show high-affinity ${ }^{3} \mathrm{H}$-histamine uptake (Rafalowska et al., 1987; Huszti et al., 1990). For invertebrates, histaminergic neurons identified in molluscs (Turner and Cottrell, 1977; McCaman and Weinreich, 1985) take up ${ }^{3} \mathrm{H}$-histamine selectively (Turner and Cottrell, 1977; Osborne et al., 1979; Turner et al., 1980; Schwartz et al., 1986; Elste et al., 1990). In Aplysia, this uptake is reported to be $\mathrm{Na}^{+}$-dependent (Schwartz et al., 1986).

\section{Distribution of label in the photoreceptor neuron}

It might seem peculiar at first glance that the uptake of ${ }^{3} \mathrm{H}$ histamine is not localized to transmitter release sites in the terminals but occurs all along the photoreceptor axons; however, localization of the rat brain GABA transporter by antibodies (Radian et al., 1990; Pietrini et al., 1994) shows a distribution in the axons as well as in the terminals of GABAergic neurons in culture and in situ. Attempts have also been made to localize the presumed glutamate transporter in isolated glial cells (Brew and 


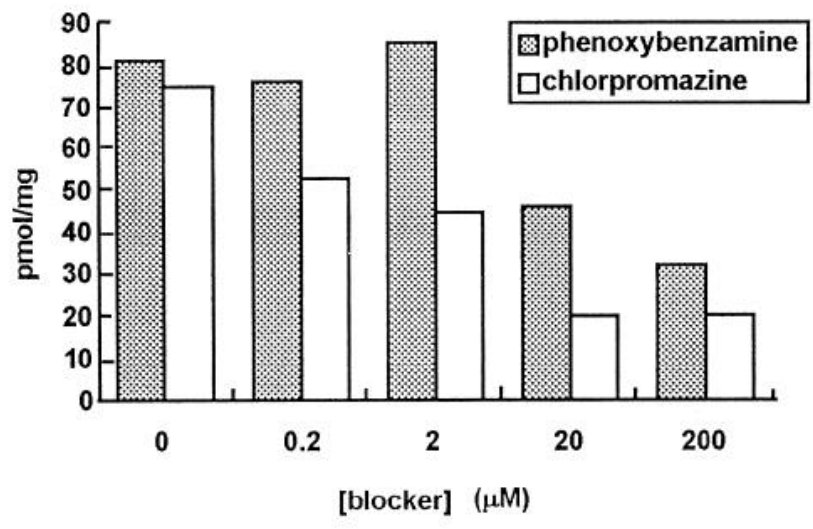

Figure 8. Dose-dependence of the antagonism of ${ }^{3} \mathrm{H}$-histamine uptake by phenoxybenzamine and chlorpromazine. Each bar represents two preparations, each preincubated for $15 \mathrm{~min}$ in the presence of the blocker and subsequently incubated under standard conditions with the blocker and 20 $\mu \mathrm{M}{ }^{3} \mathrm{H}$-histamine.

Attwell, 1987) and photoreceptors (Sarantis et al., 1988; Tachibana and Kaneko, 1988) of the vertebrate retina by iontophoresis of glutamate onto various cellular regions. Although the resolution of this approach is limited, glutamate-gated currents are maximum when glutamate is applied to the synaptic end of the photoreceptors or the endfeet of the glia cells, indicating polarity in the distribution of the uptake mechanism.

We found only a low level of ${ }^{3} \mathrm{H}$-histamine uptake into somata of the barnacle photoreceptors under our stimulus conditions. This result may be attributable not to the relative absence of the presumed transporter from the somatic membrane but to the $\mathrm{Na}^{+}$-dependence of the process: the somata would be expected to be depolarized for a good part of the incubation period by the light, causing a marked reduction in the $\mathrm{Na}^{+}$gradient across the membrane. After incubation of molluscan ganglia in ${ }^{3} \mathrm{H}-$ histamine, label is found over somata of histaminergic cells (Turner and Cottrell, 1977; Schwartz et al., 1986). On the other hand, the rat brain GABA transporter was not found in somata of neurons or of glial cells (Radian et al., 1990; Pietrini et al., 1994) and is targeted to the apical but not the basolateral membrane when expressed in polarized epithelial cells. The question of whether the histamine uptake mechanism is present throughout the barnacle photoreceptor or specifically in the axonal/synaptic domain requires further investigation.

\section{${ }^{3} \mathrm{H}$-histamine uptake by terminals in the light and dark}

$\mathrm{Na}^{+}$-dependent transporters typically take up their transmitter more avidly when the cell is relatively hyperpolarized and the $\mathrm{Na}^{+}$ gradient is comparatively large (Tachibana and Kaneko, 1988; Cammack and Schwartz, 1993), but we observed the opposite result for the photoreceptor terminals, which label more crisply in the light or flashing light when they are relatively depolarized than

Figure 9. Four preparations selected to represent the range of observations of labeling of ganglia incubated in ${ }^{3} \mathrm{H}$-histamine in the dark. Phasecontrast images of sections through the entering photoreceptor axons or primary processes (arrows) and region of presynaptic terminals. The axons do not label as heavily as do their surrounding glia. $A$, Region of photoreceptor terminals. No labeled terminals were found in this or any other section. The heavy, diffuse label of the anterior compartment is primarily over glia (compare Fig. $1 A, B$ ). $B$, An axon sectioned at its bifurcation
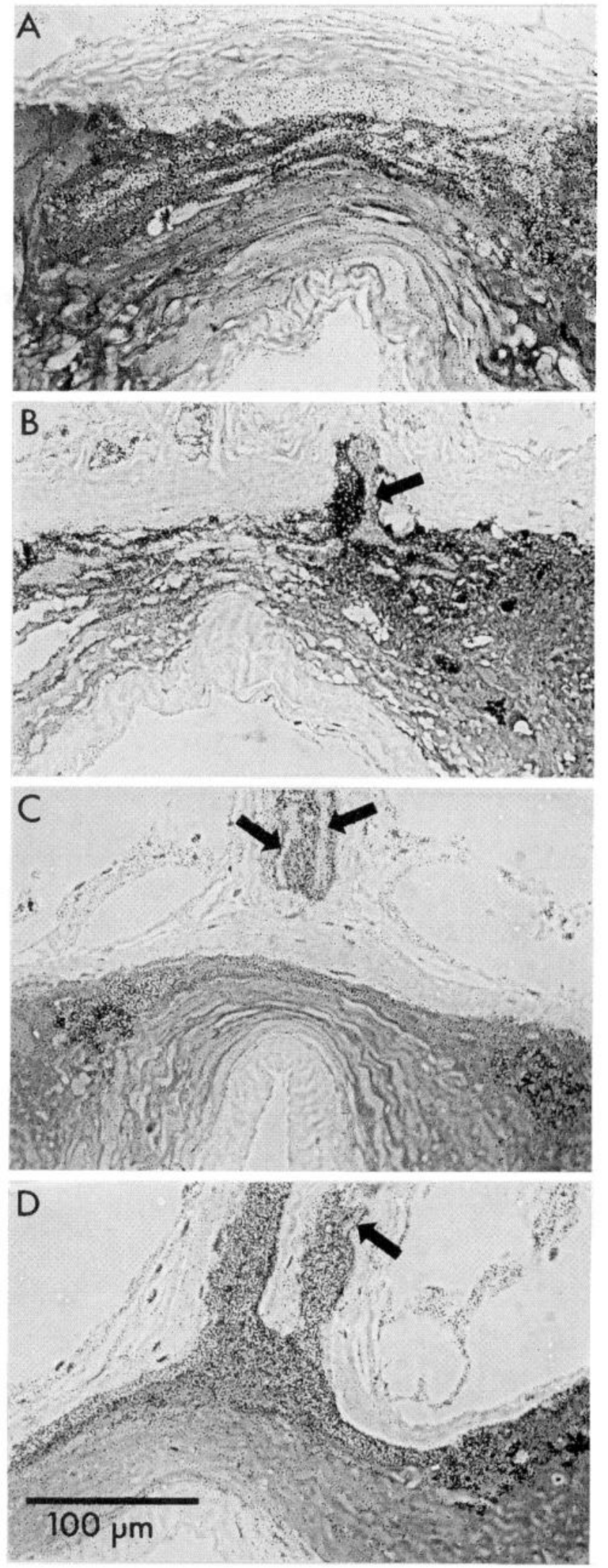

point. $C$, Two primary processes of an axon that has bifurcated at a more distal point. $D$, Section through the glial sheaths of two groups of primary photoreceptor processes illustrating the heavy glial labeling. Arrow points to the only photoreceptor axonal profile in the section. Scale bar in $D$ applies to all panels. 
they do in the dark, when they are relatively hyperpolarızed In the dark, label seems stronger over glıa

Uptake into the presynaptic terminals might be influenced by factors in addition to the $\mathrm{Na}^{+}$gradient in this specialized region More active uptake might occur in the light if the intracellular histamine concentration falls when the cell depolarizes and releases transmitter, either because of the release itself or because the histamine is scquestered more actively into a vesicular pool during transmitter recycling It is also possible that uptake might be linked to other presynaptic processes involved with transmitter release, such as on or second messenger changes In this regard, it will be of interest to examine how uptake into nonsynaptic regıons of the cell depends on light and dark

\section{REFERENCES}

Amara SG, Kuhar MJ (1993) Neurotransmitter transporters recent progress Annu Rev Neurosei 16 73-93

Ayoub GS, Lam DM-K (1987) Accumuldtion of $\gamma$-aminobutyric acid by horizontal cells isolated from the goldfish retind Vision Res 27 2027-2034

Battelle B-A, Calman BG, Andrews AW, Grieco FD, Mlezıva MB, Callaway JC, Stuart AE (1991) Histamine a putative dfferent neurotransmitter in Limulus eyes J Comp Neurol 305 527-542

Brew H, Attwell D (1987) Electrogenic glutamate uptake is a major current carrier in the membrane of axolotl retinal glial cells Nature 327 707-709

Burg MG, Sarthy PV, Koliantz G, Pak WL (1993) Genetic and molecular identıfication of a Drosophtla histidine decarboxylase gene required in photoreceptor transmitter synthesis EMBO J 12 911-919

Callaway JC, Stuart AE (1989a) Companison of the responses to light and to GABA of cells postsynaptic to barnacle photoreceptors (I-cells) Vis Neurosci 3 301-310

Callaway JC Stuart AE (1989b) Bıochemıcal and physıologıcal evidence that histamine is the transmitter of barnacle photoreceptors Vis Neu$10 \mathrm{ce} 3311-325$

Callawdy JC, Lasser-Ross N, Stuart AE, Ross WN (1993) Dynamıcs of intracellular free calcium concentration in the presynaptic arbors of individual barnacle photoreceptors $\mathbf{J}$ Neuroses 13 1157-1166

Callaway JC, Masinovsky B, Edwards JS (1985) Immunocytochemical study of arthropod neurons with antıbodics specific to molluscan small cardıoactıve peptıde and serotonin a comparatıve study Soc Neuroseı Abstr 11326

Callawdy JC, Stuart AE, Edwards JS (1989) Immunocytochemical evidence for the presence of histamine and GABA in the photoreceptors of the barnacle, Balanus nubulus Vis Neurosc1 3 289-299

Cammack JN, Schwartz EA (1993) Ions required for the electrogenıc transport of GABA by horizontal cells of the catfish retına $J$ Physiol (Lond) 472 81-102

Elias MS, Evans PD (1983) Histamine in the insect nervous system distribution, synthesis and metabolism $J$ Neurochem 41 562-568

Elias MS, Evans PD (1984) Autoradıographic localization of ${ }^{3} \mathrm{H}-$ histamine accumulation by the visual system of the locust Cell Tissue Res 238 105-112

Elste A, Koester J, Shapıro F, Panula P, Schwartz JH (1990) Identification of histaminergic neurons in Aplysia J Neurophysiol 64 736-744

Fahrenbach WH (1965) The micromorphology of some simple photoreceptors Z Zellforsch 66 233-254

Hardie RC (1987) Is histamine a neurotransmitter in insect photoreceptors? J Comp Physiol [A] 161 201-213

Hardie RC (1988) Effects of antagonists on putative histamine receptors in the first visual neuropile of the houscfly (Musca domestuca) J Exp Biol 18 221-241

Hardie RC (1989) A histamıne-dctivated chloride channel involved in neurotransmission at a photoreceptor synapse Nature 339 704-706

Hart MK, Battelle B-A (1991) Histamine metabolism and release in the Limulus visual system Invest Ophthalmol $\mathrm{V}_{\mathrm{SS}} \mathrm{Scl} 321151$

Hudspeth AJ, Stuart AE (1977) Morphology and responses to light of the somata, axons, and termmal regions of individual photoreceptors of the giant barnacle J Physiol (Lond) 272 1-23

Hudspeth AJ, Poo MM, Stuart AE (1977) Passive signal propagation and membrane properties in median photoreceptors of the giant barnacle J Physiol (Lond) 272 25-43
Husztı Z, Rımanoczy A, Juhasz A, Magyar K (1990) Uptake, metabolısm, and release of ${ }^{3} \mathrm{H}$-histamıne by glial cells in primary cultures of chıck ceicbral hemıspheres Glıa 3 159-168

Ludowyke RI, Lagunoff D (1986) Amıne uptake into intact mast cell granules in vitro B1ochemistry 2562876293

McCaman RE, Weinıeich D (1985) Histamınergic synaptıc transmission in the cerebral ganglıon of Aplysia J Neurophysiol 53 1016-1037

Morgan JR, Stuart,AE (1995) Subcelluldı distribution of a putative transporter for the transmitter histamine in an arthropod photoreceptor Soc Neurosci Abstr 21867

Oland LA, Studrt AE (1986) Pattern of convergence of the receptors of the barnacle's three ocelli onto second-order cells J Neurophysiol $55882-895$

Osborne NN, Wolter KD, Neuhoff V (1979) In vitro experıments on the accumulation and reledse of ${ }^{14} \mathrm{C}$-histamme by snail (Helix pomatia) nervous tissue Biochem Pharmacol 28 2799-2805

Panuld P, Alraksinen MS (1991) The histaminergic neuronal system as reveded with antisera dgainst histamine in Histaminergic neurons morphology and function (Watanabe T, Wada H, eds), pp 127-143 Bocd Raton CRC

Pıetrını G, Young JS, Edelmann L, Rudnıck G, Caplan MJ (1994) The axondl $\gamma$-aminobutyric acid transporter GAT-1 is sorted to the apical membranes of polarized epithelial cells J Biol Chem 269 4668-4674

Radidn R, Ottersen OP, Storm-Mathısen JS, Castel M, Kanner BI (1990) Imunocytochemical localization of the GABA transporter in rat brain J Neurose1 $101319-1330$

Rafalowska U, Waskiewicz J, Albrecht J (1987) Is neurotiansmitter histamine predominantly inactivated in astrocytes? Neurosel Lett $80106-110$

Sarantıs M, Everett K, Attwell D (1988) A presynaptic action of glutamate at the cone output synapse Nature 332 451-453

Sarthy PV (1991) Histamıne d neurotransmitter candidate for Drosophlla photoreceptors J Neurochem 5717571768

Schlemermeyer E, Schutte M, Ammermuller J (1989) Immunohistochemical and electrophysiological evidence that locust ocellar photoreceptors contan and release histamine Neurosci Lett 99 73-78

Schmid A, Duncker M (1993) On the function of histamine in the central nervous systcm of arthiopods Acta Biologica Hung 44 67-75

Schnapp BJ, Stuart AE (1983) Synaptıc contacts between physiologically identified neuions in the visual system of the barnacle $\mathbf{J}$ Neurosc1 $31100-1115$

Schwartz EA, Tachıbana M (1990) Electrophysılogy of glutamate and sodium co-transport in a glial cell of the salamander retina J Physiol (Lond) 426 43-80

Schwartz JC, Arrang JM, Garbarg M, Pollard H, Ruat M (1991) Histaminergic transmission in the mammalian brain Physiol Rev 71 1-51

Schwartz JH, Elste A, Shapiro E, Gotoh H (1986) Biochemical and morphological correlates of transmitter type in $\mathrm{C} 2$, an identified tustaminergic neuron in Aplysia J Comp Neurol 245 401-421

Simmons PJ, Hardie RC (1988) Evidence that histamine is a neurotransmitter of photoreceptors in the locust ocellus J Exp Biol 138 205-219

Stockbridge NL, Ross WN (1984) Localızed Ca and calcium-dctivated potassium conductances in terminals of a barnacle photoreceptor $\mathrm{Na}$ ture 309 266-268

Stuart AE, Callaway JC (1991) Histamine the case for a photoreceptor's neurotransmittel Neurosc1 Res [Suppl] 15 S13-S23

Stuart AE, Mekeel HE (1990) Uptake of histamine into the presynaptic terminals of barnacle photoreceptors (Abstr) Invest Ophthalmol Vis Sc1 31335

Stuart AE, Schmıd EC, Mekeel HE (1993) Chlorpromazıne blocks the uptake of histamine into presynaptic terminals of barnacle photoreceptors and affects signals generated in the postsynaptic cell Soc Neurosel Abstr 19938

Tachiband M, Kaneko A (1988) L-glutamate-ınduced depoldızatıon in solitary photoreceptors a process that may contribute to the interaction between photoreceptors in situ Proc Natl Acad Sc1 USA 85 5315-5319

Tumer JD, Cottreil GA (1977) Pioperties of an identrfied histaminecontannng neurone Nature 267 447-448

Turner JD, Powell B, Cotrell GA (1980) Morphology and ultrastructure of an identified histamine-containing neuron in the central nervous system of the pond snal, Lymnaea tagnalss $L$ J Neurocytol 9 1-14

Weinreich D (1979) $\gamma$-Glutamylhistamine a major product of histamine metabolism in the marine mollusc Aplysia californica J Neurochem 32 363-369 